\title{
EVOLUTION OF A DISLOCATION STRUCTURE DURING THE GROWTH SILICON SINGLE CRYSTALS OF $n$ - AND $p$-TYPE
}

\author{
N.A. Azarenkov, V.E. Semenenko, N.G. Stervoyedov \\ V.N. Karazin Kharkiv National University, Kharkiv, Ukraine
}

The kinetics of the formation of perfect $n$ - and $p$-type silicon single crystals is considered. The peculiarity of the formation of point and linear defects in the process of a controlled phase transformation of a liquid-solid is established. The effect of supersaturation by vacancies of the direction of predominant growth and concentration of impurities on the formation and removal of edge and screw dislocations is determined. The effect of linear defects on the scattering and recombination of mobile current carriers is revealed. The possibilities of increasing the stability and efficiency of silicon semiconductor devices are discussed.

PACS: 81.10.Fg, 88.40.jj, 78.40.Fuy, 81.40.-z, 85.40.Ry, 72.10.Fk

\section{INTRODUCTION}

At present energy and environmental issues make it necessary to develop non-traditional energy sources along with nuclear energy, among which solar energy occupies a prominent place. The high purity of the initial matrix components of semiconductors, used to create solar battery (SB), is due to the low concentration $\left(10^{-5} \ldots 10^{-7}\right.$ wt. \%) of doping acceptor and donor impurities that noticeably change their electronic properties [1, 2]. Doping of pure silicon with phosphorus (approximately $10^{-3}$ at.\%) leads to $10^{6}$ decrease in the electrical resistance of an $n$-type semiconductor. A few ppm of As leads to a 1000-fold increase in Ge conductivity (at $300 \mathrm{~K}$ ). These results are explainable when comparing the energy spectrum of the alloying and matrix semiconductor components, the band gap $[3,8,9,19]$.

The average annual solar radiation incident on the territory of Ukraine ranges from 1000 to $1600(\mathrm{~kW} \cdot \mathrm{h}) / \mathrm{m}^{2}$. This allows the use of solar converters on the roofs and windows of high-rise buildings, etc.

The use of semiconductor materials in solid-state electronics and in various areas of alternative energy makes it necessary to obtain them in a single-crystal form with a structure close to perfect, which is the main objective of this work.

The majority of works indicate the degradation of the electronic properties of materials of solar cells (SC), however, there are practically no structural studies of SB elements, a detailed analysis of the influence of point and linear defects on dimensional and structural stability, coefficient of performance (efficiency), etc.

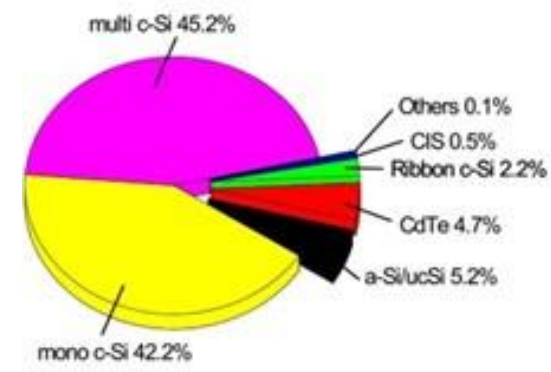

Fig. 1. Semiconductor materials that are used for SC and their share of the total

As can be seen from Fig. 1, the basic material for the creation of SB is indirect-gap silicon-amorphous, poly- and single-crystal. The SB efficiency on the basis of such silicon is 15,17 , and more than $25 \%$, respectively. Photoconverters based on amorphous silicon are rather cheap, but they have low power and insignificant structural stability. Using the achievements of nanotechnology can improve the characteristics of flint SB [7, 12]. Of undoubted interest are devices (second generation SB) based on thin films (CdTe), however, the toxicity of materials is a serious obstacle to film technology. Devices with high efficiency and low cost are used (the third generation of SB), which increases the energy efficiency $[3,5,6,17]$.

Fig. 2 shows the structural diagram of the SB, showing the $n-p$ junction, the main elements of the SB. There is a contact system for collecting and removing electrons into an external circuit on the surface of the semiconductor structure. On the front illuminated surface of the converter the contacts are made in the form of a grid or a comb, and on the back they can be solid.

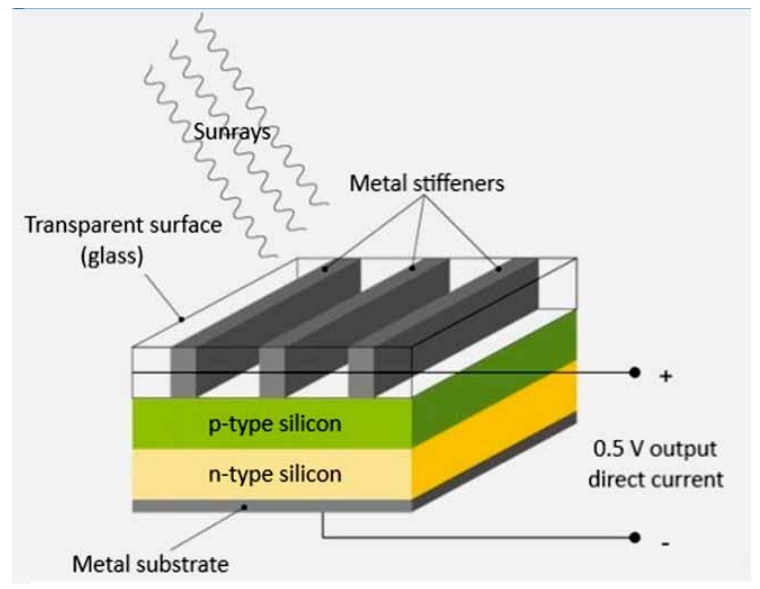

Fig. 2. Structural diagram of the $S B$

The main irreversible losses of solar cells are caused by:

- reflection of solar radiation from the surface of the PEC;

- passage of part of the radiation through the PEC without absorption in it;

- dissipation of excess photon energy by thermal vibrations of the lattice;

- recombination of the formed photocouples on the surfaces and in the volume of the PEC; 
- converter internal resistance and some other physical processes.

To reduce all types of energy losses in PEC, the following are used: semiconductors with the band gap optimal for solar radiation; directed improvement of the properties of the semiconductor structure by its optimal alloying and the creation of built-in electric fields; transition from homogeneous to heterogeneous and graded-gap semiconductor structures; optimization of the design parameters of the photomultiplier (the depth of the $p-n$ junction, the thickness of the base layer, etc.); the use of multifunctional optical coatings that provide enlightenment, thermoregulation, and protection of SC from cosmic radiation.

The optimal materials for transforming the solar spectrum are $\mathrm{Si}$, In $\mathrm{Sb}, \mathrm{AsGa}, \mathrm{CdTe}, \mathrm{A}^{\mathrm{III}} \mathrm{B}^{\mathrm{V}}$ band gap $\varepsilon_{\mathrm{g}}=1.3 \ldots 1.5 \mathrm{eV}$. Despite the fact that silicon has $\varepsilon_{\mathrm{g}}=1.21 \ldots 3.6 \cdot 10^{-4} \mathrm{eV}$, which is less than the optimal theoretical value. The observed changes in the silicon band gap under the influence of acceptor and donor impurities determine the real work of SB based on widely distributed in nature silicon, which makes up $27.6 \%$ of the earth's crust.

The absorption spectrum of silicon in PEC is similar to the spectrum of solar radiation. Using silicon you can convert $\approx 91 \%$ of the incident solar radiation (see Fig. 2) with a wavelength of $\approx 1 \mu \mathrm{m}$. It should be noted that silicon PECs have a theoretical marginal efficiency of $30 \%$ under standard conditions - illumination of $1 \mathrm{~kW} / \mathrm{m}^{2}, T=300 \mathrm{~K}$, air mass $\mathrm{AM}=1.3$.

The calculations show that to eliminate large recombination losses at the grain boundaries (SB), the grain size of the silicon crystal should be about several millimeters. This condition means that the size of one grain must exceed the thickness of one SC, reducing the resistance to current carriers and the total length (multicrystalline silicon $\mathrm{SB}$ ). Table 1 shows the main data of silicon SC.

Table 1

Crystalline silicon SC

\begin{tabular}{|c|c|c|c|}
\hline Title & Designation & $\begin{array}{c}\text { Grain } \\
\text { size }\end{array}$ & $\begin{array}{c}\text { Growing } \\
\text { technology }\end{array}$ \\
\hline Monocrystal & $\mathrm{sc}-\mathrm{Si}$ & $>10 \mathrm{~cm}$ & $\begin{array}{c}\text { Czochralski, } \\
\text { zone melting }\end{array}$ \\
\hline Multicrystal & $\mathrm{mc}-\mathrm{Si}$ & $1 \mathrm{~mm}-$ & $\begin{array}{c}\text { Casting, thin } \\
\text { sheets, } \\
\text { ribbons }\end{array}$ \\
\hline Polycrystal & $\mathrm{pc}-\mathrm{Si}$ & $\begin{array}{c}1 \mu \mathrm{m}- \\
1 \mathrm{~mm}\end{array}$ & $\begin{array}{c}\text { Chemical } \\
\text { vapor } \\
\text { deposition }\end{array}$ \\
\hline Microcrystal & $\mathrm{uc}-\mathrm{Si}$ & $<1 \mu \mathrm{m}$ & $\begin{array}{c}\text { Plasma } \\
\text { deposition }\end{array}$ \\
\hline
\end{tabular}

It was found that the thickness of a SC with a size of $\approx 100 \mu \mathrm{m}$ is necessary to reduce the resistance of currents of charge carriers. It should be noted that monocrystalline silicon is the most suitable element of the SB is clear that the dimensions of a single grain of silicon should exceed the thickness of one SC, reducing the resistance to current carriers and the total length of the boundaries (multicrystalline silicon samples). Along with the purity of solar silicon SOG-Si (solar grad 99.999\%) To eliminate the degradation of the properties of PEC, perfect single crystals with a controlled structure and properties are needed.

The aim of this work is to increase the stability of SB due to the perfection of the structure of doped silicon single crystals, to study the kinetics of their formation under conditions of a controlled liquid-crystal phase transformation. Clarification of the mechanism of the occurrence and removal of edge and screw dislocations - sources of vacancies and scattering centers, recombination of mobile current carriers of semiconductors.

\section{INITIAL MATERIALS AND EXPERIMENTAL TECHNIQUE}

The starting material is polycrystalline silicon (SOG-Si), the impurity composition of which was, ppm: $\mathrm{B}-0.3\left(1.16 \cdot 10^{-5}\right) ; \mathrm{Al}-0.1\left(9.6 \cdot 10^{-8}\right) ; \mathrm{C}-3\left(1.29 \cdot 10^{-9}\right)$; $\mathrm{Fe}-0.03\left(5.98 \cdot 10^{-3}\right) ; \quad \mathrm{Ni}-0.1\left(2.1 \cdot 10^{-7}\right) ; \quad \mathrm{Zn}-$ $0.1\left(2.34 \cdot 10^{-7}\right)$; O $-10\left(5.7 \cdot 10^{-6}\right)$; $\mathrm{Cr}-0.01\left(1.86 \cdot 10^{-8}\right)$. Phosphorus was used as a donor impurity (1.4 ppm), acceptor boron (2.6 ppm). Dopants form solid substitution and incorporation solutions. In silicon acceptor impurities diffuse faster than donor impurities. The latter is due to a significant difference in the ionic radii of the acceptor and the main substance; the effect is not masked by the Coulomb interaction between ions and charged vacancies [3].

Silicon monocrystals of $p$ - and $n$-type with resistivity $10^{-3} \ldots 200 \Omega \cdot \mathrm{cm}$ obtained by directed crystallization (vacuum less then $10^{-4}$ Torr - in some cases, in an inert helium medium (pressure less than 30 Torr) (Fig. 3).

Metallographic, X-ray diffraction (DRON-4M), electron microscopic (TEM) analyzes were performed. The microstructure was revealed by anodic etching of $n$ and $p$-type samples taking into account their electron and hole conductivity. It was determined that the anode behavior of the $p$-type electrode is similar to the behavior metal, $n$-type is determined by the rate at which holes enter the electrode surface.

\section{RESULTS AND DISCUSSION}

Monocrystalline silicon of $n$ - and $p$-type was grown by controlled directional crystallization (Czochralski method) using oriented seeds. The advantage of methods for growing crystals from a melt is the simplicity of specifying a certain geometric shape and size for samples at a certain stage of their growth, the absence of direct contact between the walls of the crucible and the melt, which reduces the content of impurities in the finished product. The need to obtain doped silicon samples in a single crystalline form is due to the fact that they exhibit a significantly lower electric charge dispersion in comparison with polycrystalline samples $[8,9]$.

Structural analysis of a silicon monocrystal, grown with high crystallization rates $(R>100)$ showed that the monograin did not have a definite orientation throughout the volume, and subsequent annealing led to the formation of a substructure. The maximum solubility and concentration of dopants in the samples are given in Table 2. 
It is known that the growth of crystals from a melt is similar to a single pass of the molten zone (zone recrystallization), and there is a slight cleaning of impurities such as arsenic, germanium, and phosphorus [10]. Purification from interstitial impurities $(\mathrm{C}, \mathrm{N}, \mathrm{O})$ is observed, which have a negative effect on the electronic properties of silicon.

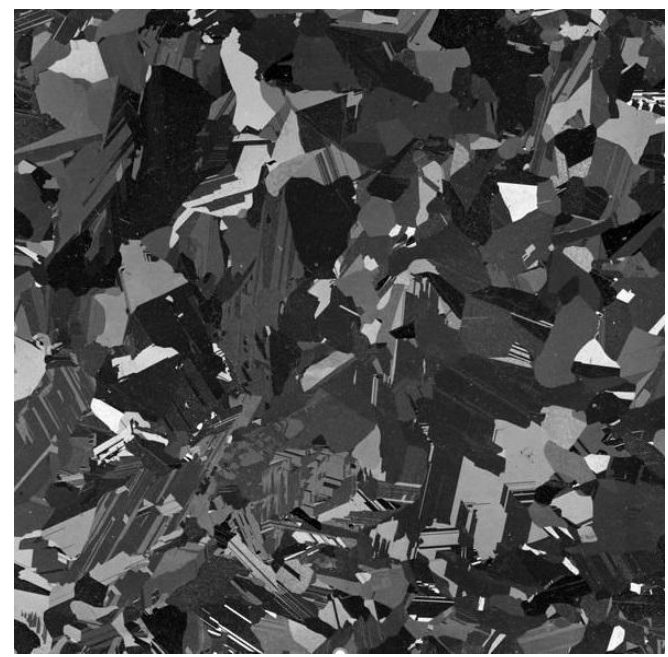

Fig. 3. Polycrystalline silicon

Table 2

Impurity composition of silicon single crystals

\begin{tabular}{|c|c|c|c|}
\hline $\begin{array}{c}\text { Impu- } \\
\text { rity } \\
\text { element }\end{array}$ & $\begin{array}{c}\text { Solubility } \\
\text { at } 300 \mathrm{~K}, \\
\text { wt.\% }\left(\mathrm{cm}^{-3}\right)\end{array}$ & $\begin{array}{c}\text { Maximum } \\
\text { solubility at } \\
T=0.9 T_{\mathrm{mlt}}\end{array}$ & $\begin{array}{c}\text { Impurity } \\
\text { concentration } \\
\text { in samples, } \\
\text { wt.\% }\left(\mathrm{cm}^{-3}\right)\end{array}$ \\
\hline B & $\begin{array}{c}10^{-3} \\
\left(1.3 \cdot 10^{18}\right)\end{array}$ & $\begin{array}{c}3.8 \cdot 10^{-1} \\
\left(5 \cdot 10^{20}\right)\end{array}$ & $\begin{array}{c}10^{-5} \\
\left(1.6 \cdot 10^{16}\right)\end{array}$ \\
\hline P & - & $2.8\left(1.3 \cdot 10^{21}\right)$ & $1.5 \cdot 10^{-5}$ \\
& - & $0.8\left(3.6 \cdot 10^{20}\right)$ & $\left(6.8 \cdot 10^{15}\right)$ \\
\hline
\end{tabular}

As established, the carbon content in the grown crystals is approximately $5 \cdot 10^{16} \ldots .5 \cdot 10^{17} \mathrm{~cm}^{-3}$. Solubility of carbon in a molten silicon at a melting point of approximately $(2 \ldots 4) \cdot 10^{18}$, in monocrystals $6 \cdot 10^{17} \mathrm{~cm}^{-3}$. The effective distribution coefficient of carbon in silicon $k=0.07$. It was determined that the main source of carbon in the grown crystals is the initial polycrystalline silicon, as well as mono and silicon dioxide. To reduce the likelihood of the formation of carbon oxides tungsten heaters were used instead of the usual graphite oxidized, oxygen plants used in thermal units [11].

To reduce the oxygen content in silicon crystals, we used crucibles made of boron nitride that do not interact with silicon. It is determined that the presence of large quantities of oxygen $\left(1.5 \cdot 10^{19} \mathrm{~cm}^{-3}\right)$ in silicon ingots leads to the appearance of a characteristic absorption band of light by silicon crystals. This band is at about $9 \mu \mathrm{m}$. It was found that the optical absorption coefficient measured at $9 \mu \mathrm{m}$ on various samples, varies depending on the oxygen content in them (Fig. 4). Nitrogen content in silicon crystals $10^{12} \mathrm{~cm}^{-3}$ $\left(10^{-7}\right.$ wt.\%), solubility limit in solid silicon $4.5 \cdot 10^{15} \mathrm{~cm}^{-3}$, equilibrium distribution coefficient $k=0.05$, sources of nitrogen - gas atmosphere.
It was found that nitrogen, as a donor impurity, leads to an increase in the critical stress of the formation of dislocations in silicon. In the obtained silicon single crystals, the nitrogen content $10^{9} \mathrm{~cm}^{-3}$, oxygen $2 \cdot 10^{15} \mathrm{~cm}^{-3} \quad\left(2.29 \cdot 10^{-6} \mathrm{wt} . \%\right)$, carbon less than $5 \cdot 10^{16} \mathrm{~cm}^{-3}\left(4.29 \cdot 10^{-5}\right.$ wt. \%) [13, 14].
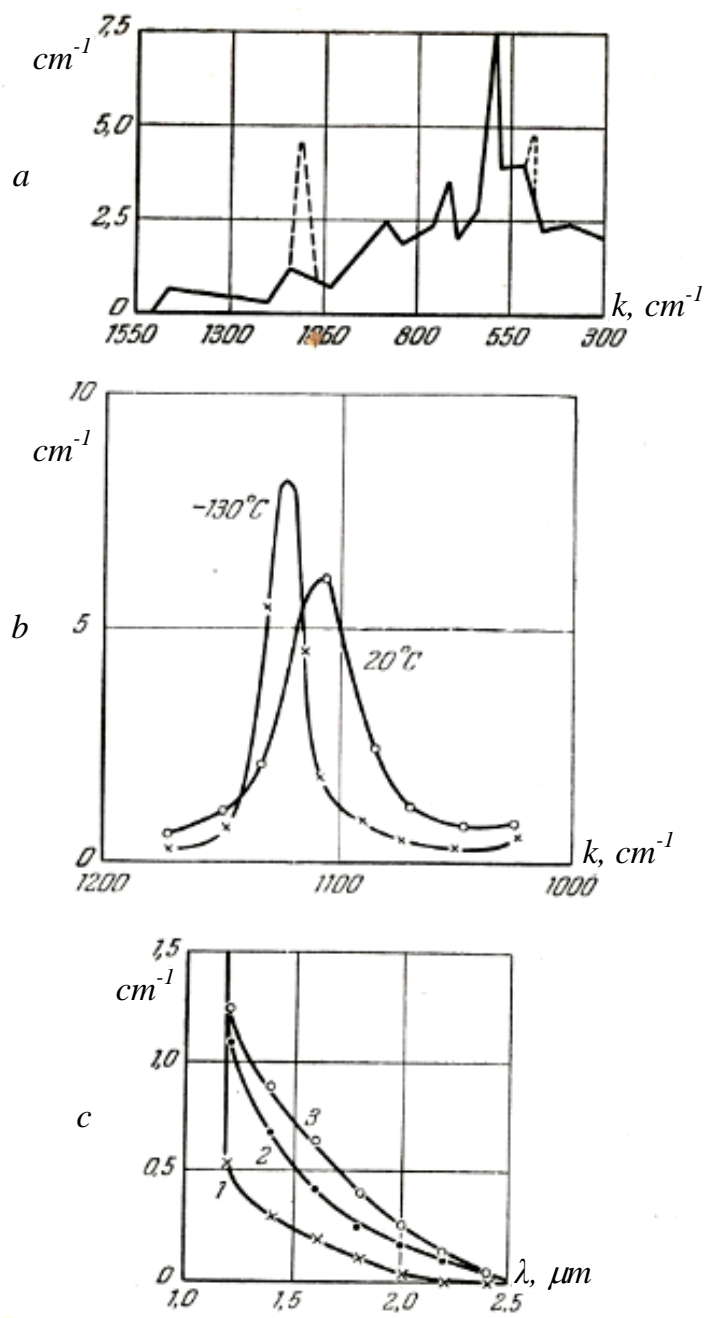

Fig. 4. Absorption of infrared radiation in silicon: $a$-absorption spectrum of silicon (solid line - free of oxygen, dashed line - additional bands due to oxygen);

6 ...9 $\mu$ m absorption band in silicon at room

temperature and at $-130{ }^{\circ} \mathrm{C}$; $\mathrm{c}$ - "tail" of the absorption band in silicon: 1 - before heat treatment, 2 - after heat treatment, 3 -for a sample free of oxygen.

The ordinate shows the absorption coefficient;

$$
\lambda \text {-wavelength, } k=2 \pi / \lambda-\text { wave number }
$$

Most literary sources indicate the use of dislocationfree crystals (whickers) of silicon used in solar energy. Such perfect crystals are observed in natural microcomposites in which the dislocation density $\rho_{\mathrm{d}} \sim 10^{1} \ldots 10^{2} \mathrm{~cm}^{-2}[10,15]$.

In order to establish the possibility of obtaining lowdislocation silicon crystals, the growth was carried out from oriented seeds. The "pinch" method was used obtaining crystals of small diameter to facilitate the exit (creep) conditions of dislocations and to eliminate the possibility of their penetration from the seed into the growing crystal (Fig. 5). 

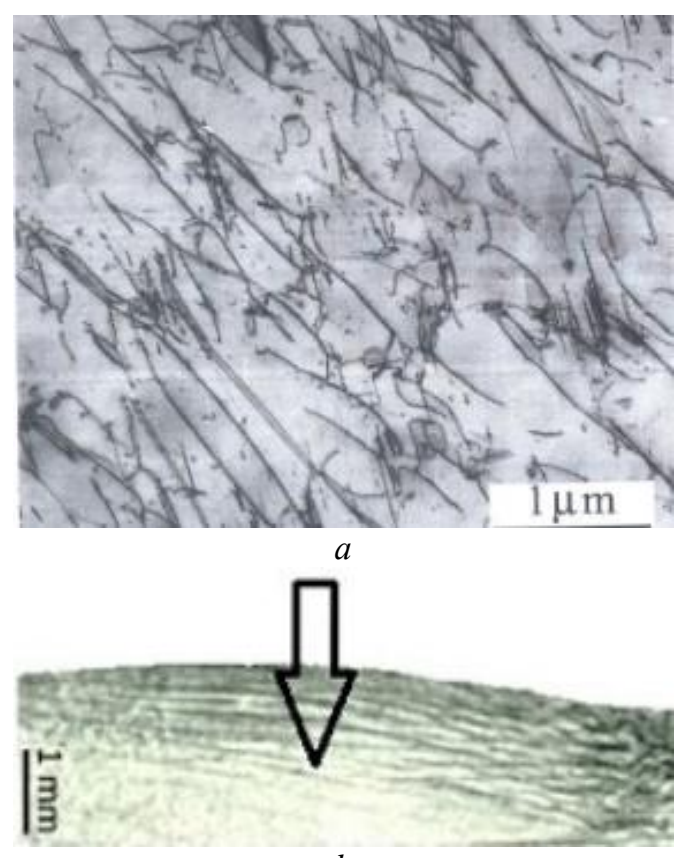

b

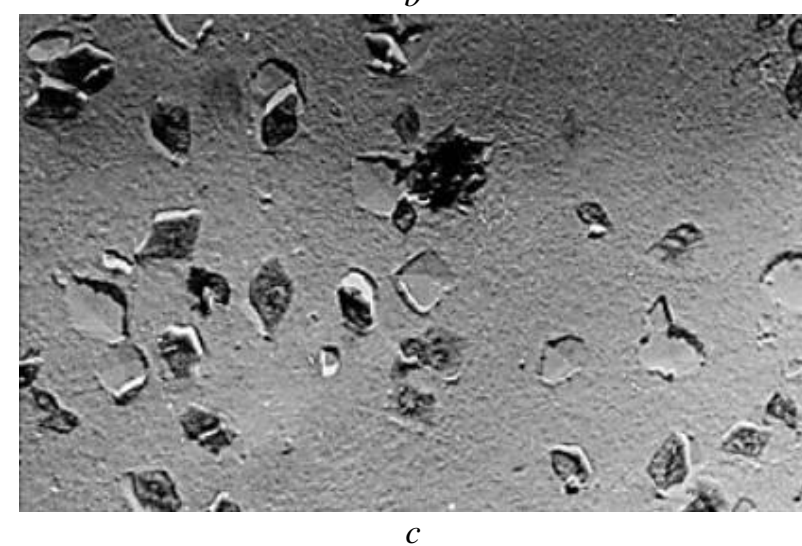

Fig. 5. The dislocation structure of silicon single crystals: $a$-dislocation density $\sim 10^{5} \mathrm{~cm}^{-2}$;

$b$ - the arrow indicates decorated dislocations; $c$-etching pits, $x 1150$

Subsequently the crystal was grown to the required size of approximately $30 \ldots 40 \mathrm{~mm}$. It should be noted that when the dislocations are eliminated, further generation of dislocations in the growing crystal does not occur, which is of undoubted interest in terms of obtaining perfect monodislocation crystals used in SB devices.

It has been established that "crawling" is due to the supersaturation of the growing crystal with vacancies.

According to calculations at room temperature the equilibrium concentration of silicon vacancies is $10^{7} \ldots 10^{8} \mathrm{~cm}^{-3}$, with an increase in temperature of more than $1000{ }^{\circ} \mathrm{C}$, increases to $10^{17} \ldots 10^{18} \mathrm{~cm}^{-3}$. It has been established that when edge dislocations exit onto the same crystallographic plane during their oncoming motion, a number of interstitial atoms arise (Fig. 6).

At growth rates $(R)$ of more than $100 \mathrm{~mm} / \mathrm{h}$ a high increase in vacancy concentrations (metastable SB structures) is observed.

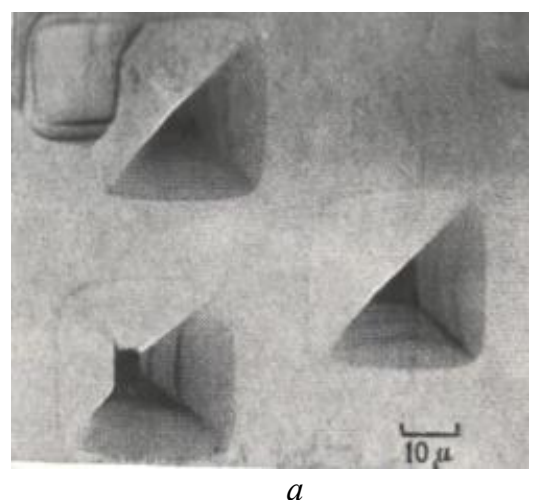

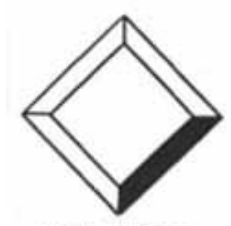

Initial position

of dislocation

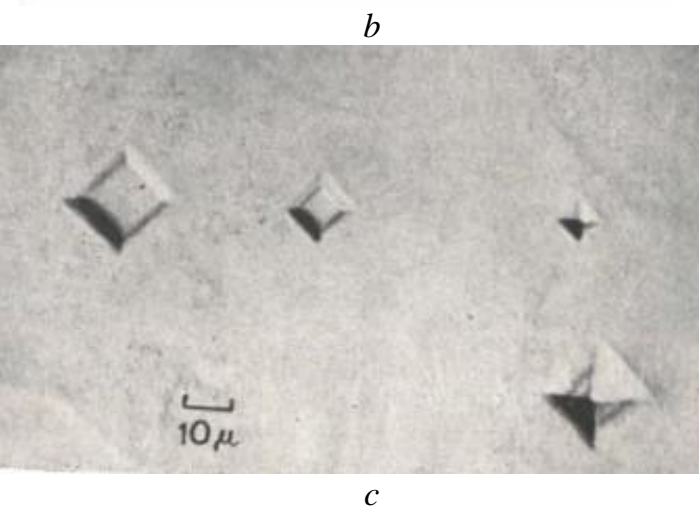

Fig. 6. Influence of dislocation movement on the shape of etching figures: $a$-etching pits formed by edge and screw dislocations; $b, c$-the effect of the movement of dislocations on the shape of etching figures

As a result the formation of vacancies near impurity atoms is facilitated, complexes of the type of Frenkel defects and their clusters are formed (A-centers).

The calculations and structural analysis show that, with the orientation of the silicon single crystals $\langle 111\rangle$ and $\langle 100\rangle$, the number of vacancies is less than with the orientations $\langle 110\rangle$ and $\langle 112\rangle$. Accordingly, the minimum dislocation density is observed in single crystals grown in the $\langle 111\rangle-\langle 100\rangle$ direction, however in crystals with the orientations $\langle 110\rangle$ and $\langle 112\rangle$ $\rho_{\mathrm{d}}>10^{4} \mathrm{~cm}^{-2}$.

The influence of the crystallization rate $(R)$ and the temperature gradient $(G)$ on the average dislocation density in the grown silicon single crystals is determined (Fig. 7).

It was determined that in order to reduce the dislocation density it is advisable to create a maximum value of $G$ not at the crystallization front, but in the volume of the growing crystal, which corresponds to the minimum value $\rho_{\mathrm{d}}=3.4 \cdot 10^{2} \mathrm{~cm}^{-2}$. The graph shows that the minimum dislocation density was observed at $G=85 \mathrm{~K} / \mathrm{cm}, R=1.5 \mathrm{~mm} / \mathrm{min}$. 


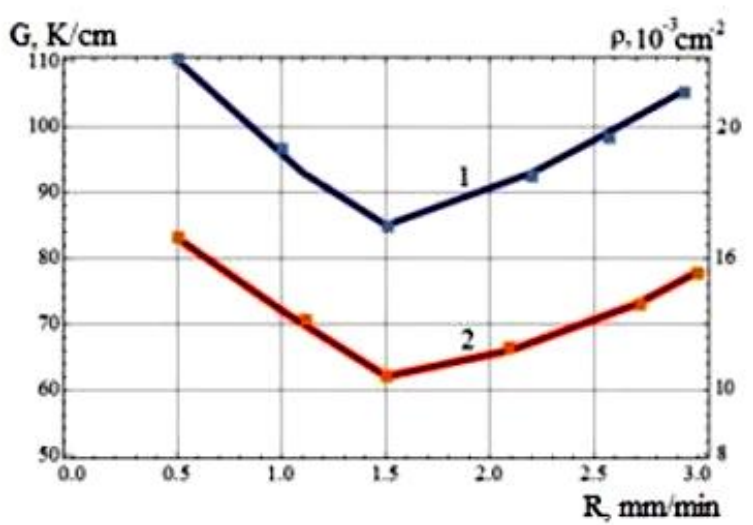

Fig. 7. Effect of crystallization rate $R$ and temperature gradient $G$ on the dislocation density:

1 - change in the temperature gradient $G$;

\section{2 - dislocation density}

The different nature of the motion and exit of edge and screw dislocations depending on the crystallization conditions was determined (see Fig. 6). It has been established that it is energetically favorable for regions of edge dislocations that are parallel to the Burgers $<111>$ vector to move into the slip plane and dissociate [16].

However in the presence of defects in single crystals, inhibition of the movement of edge dislocations by subboundaries is observed (Fig. 8), inhibition of dislocation with subboundaries.

Thus, in perfect single crystals, the edge dislocation is easier to "break the bonds" and dissociates, but the helical one remains bound undissociated (see Figs. 8, 9).

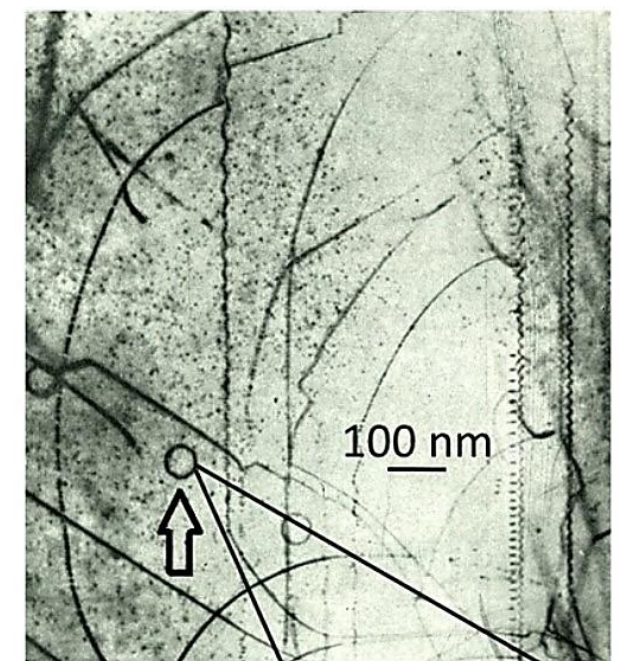

Fig. 8. Helical silicon dislocations

The structure of the dislocation affects their movement. As can be seen (see Fig. 8), a screw dislocation in silicon forms tightly compressed spirals parallel to the direction $\langle 110\rangle$. On the right side, rows of prismatic loops, probably formed by a moving dislocation, are visible. Large loops with a diameter of approximately $50 \mu \mathrm{m}$ parallel to the $\langle 111\rangle$ plane are likely stacking faults limited by partial dislocations. Thus, a screw dislocation moves slower than an edge dislocation, remains bound, undissociated. It has been determined that with a large supersaturation with vacancies of a growing crystal, a screw dislocation is a source of hexagons.
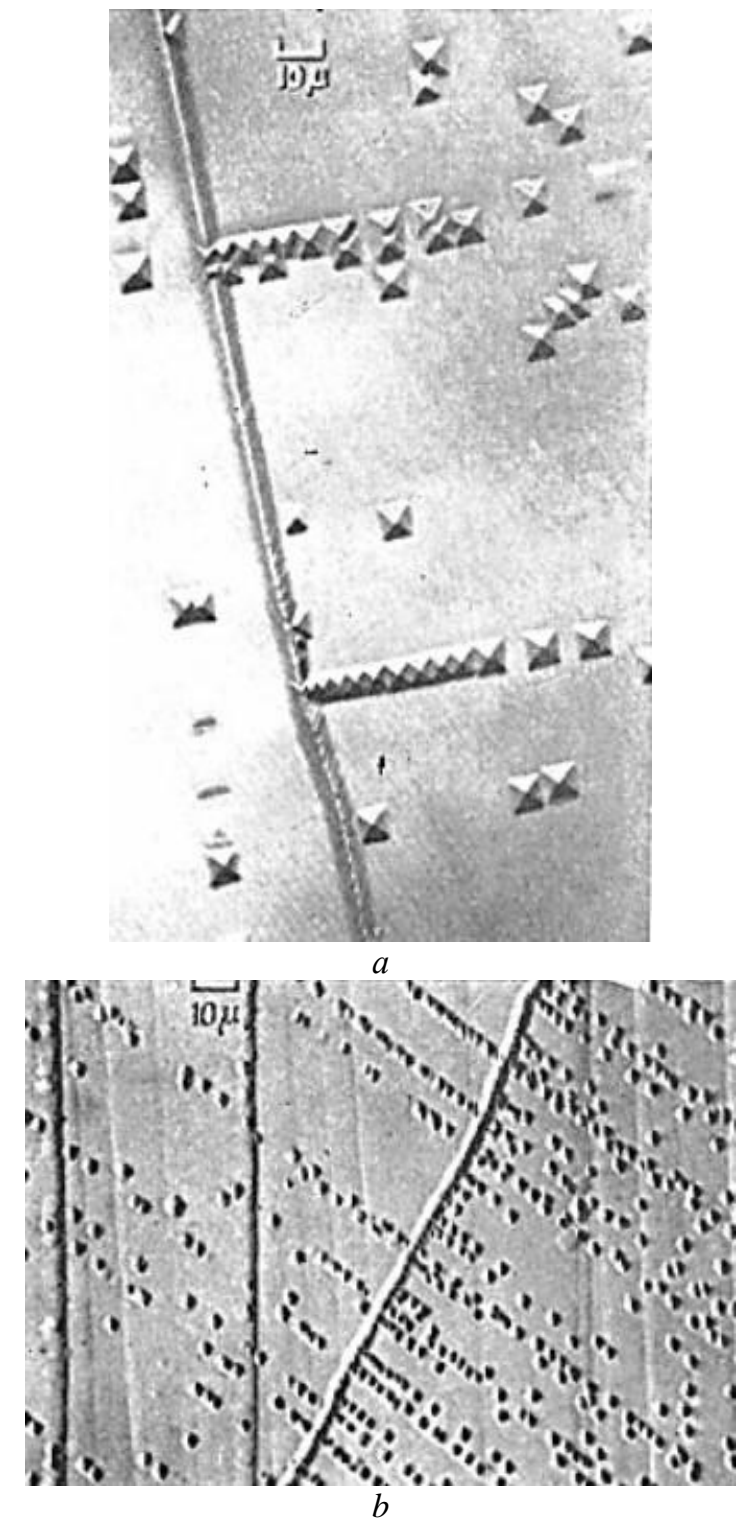

Fig. 9. Edge dislocations $(a, b)$ blocked by subboundaries in crystals

It was found that, along with vacancies, the electronic properties of semiconductors have a noticeable effect on dislocations. Dislocations create elastic stresses in the silicon lattice and deformation of energy bands, creating defect levels in the band gap of a semiconductor. It is established that the change in the band gap in doped silicon is $0.3 \ldots 0.4 \mathrm{eV}$. The presence of dislocations affects the scattering processes and the recombination of mobile current carriers. Dislocationinduced scattering decreases the carrier mobility $(\mu)$ and, accordingly, the semiconductor conductivity $(\sigma)$, determined from the relation [3]:

$$
\sigma=e\left(n_{\mathrm{n}} \mu_{\mathrm{n}}+n_{\mathrm{p}}+\mu_{\mathrm{p}}\right) \text {, }
$$

where $e$ - elemental electric charge; $n_{\mathrm{n},}, \mu_{\mathrm{n}}$, and $\mu_{\mathrm{p}}-$ concentration and mobility of electrons and holes, respectively.

The calculation of the mobility of charge carriers $(T=300 \mathrm{~K})$, which is for electrons $\mu_{\mathrm{n} \max }=$ $=1414 \mathrm{~cm}^{2} /(\mathrm{V} \cdot \mathrm{c}), \mu_{\mathrm{nmin}}=68.5 \mathrm{~cm}^{2} /(\mathrm{V} \cdot \mathrm{c})$, for holes, 
respectively $-470.5 \mathrm{~cm}^{2} /(\mathrm{V} \cdot \mathrm{c})$, and $46.9 \mathrm{~cm}^{2} /(\mathrm{V} \cdot \mathrm{c})$, where $\mu_{\max }$ - under conditions of heavy alloying $\left(10^{-4}\right.$ wt. $\left.\% \mathrm{~V}, \quad 1 \mathrm{wt} . \% \mathrm{P}\right), \quad \mu_{\min }-$ low alloying ( 10 $0^{-8}$ wt.\%) (Fig. 10).

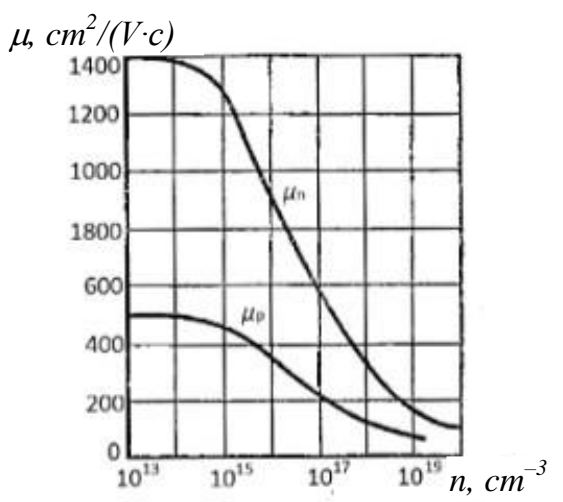

Fig. 10. The dependence of the mobility of current carriers on the concentration of the dopant $(T=300 \mathrm{~K})$

The influence of the dislocation density on the lifetime of minority current carriers is determined. It should be noted, that in pure silicon $(T=300 \mathrm{~K})$ the lifetime of minority current carriers $\tau$ is determined by the diffusion of electrons and holes, the diffusion length is determined $L_{\mathrm{d}}=\left(D_{\mathrm{d}} \tau_{\mathrm{d}}\right)^{1 / 2}$, where $D_{\mathrm{d}}$ and $\tau_{\mathrm{d}}-$ hole diffusion coefficient and time, respectively.

It is established that the scattering caused by dislocations slightly reduces the mobility of current carriers in crystals with $\rho_{\mathrm{d}}=10^{3} \ldots 10^{5} \mathrm{~cm}^{-2}$. It has been established that dislocations more significantly affect the recombination process and, consequently, the lifetime of minority current carriers, which linearly decrease with increasing dislocation density and is $\tau_{\mu \mathrm{s}}=69$ on $\rho_{\mathrm{d}}=10^{5} \mathrm{~cm}^{-2}, \tau=6.1 \mu \mathrm{s}-\rho_{\mathrm{d}}<10^{2} \mathrm{~cm}^{-2}$.

\section{CONCLUSION}

Using the method of decorating dislocations, it was possible to develop methods for controlling the structure of doped silicon single crystals and the technology for their growth.

The kinetics of the formation of low-dislocation silicon crystals is determined. It was shown that the degree of perfection of crystals depends on the initial conditions of growth, the degree of supersaturation with vacancies of the growing crystal and the direction of growth. It has been established that after the formation of a perfect low-dislocation structure in the future the growth conditions do not affect the processes of generating new dislocations, which makes it possible to obtain large-sized semiconductor crystals.

Various mechanisms for the removal of screw and edge dislocations have been revealed. The movement of edge dislocations is slowed down by subboundaries. In perfect crystals the edge dislocation "breaks the bonds easier" and moves, the screw dislocation remains undissociated, moves more slowly than mixed and edge dislocations.

It is established that the presence of dislocations creates additional local electronic levels in the energy spectrum of the crystal. Dispersion-induced scattering decreases the mobility of current carriers, slight decrease in mobility is observed in crystals $\left(\rho_{\mathrm{d}} \sim 10^{4} \ldots 10^{5} \mathrm{~cm}^{-2}(T=300 \mathrm{~K})\right)$. A significant effect of dislocations on the processes of recombination and therefore the lifetime of nonequilibrium current carriers, which linearly decrease with increasing dislocation density was found.

The results obtained show that the deep cleaning of silicon from interstitial impurities, the control of processes, the introduction of small amounts of acceptor and donor impurities, their controlled distribution along the length and cross section of samples with a minimum dislocation density $10^{2} \mathrm{~cm}^{-2}$ determines, along with an increase in the efficiency of silicon SB to $28 \ldots 29 \%$, the quality and reproducibility of the characteristics of silicon semiconductor devices.

\section{REFERENCES}

1. S.M. Liaug. Materially of Solar Battery // J. Phys. Equal and Diff. 2015, N 45, p. 35-48.

2. C. Richers. Spectral selective Reflecting Thiu-thiu Filters for laser display Technology // Thin Solid Films. 2016, v. 46, p. 145-152.

3. Н.А. Азаренков, В.Е. Семененко, В.Н. Ткаченко. Перспективные конструкционные материаль нетрадиционной и атомной энергетики: Учебнометодическое пособие. Харьков: ХНУ, 2016, 109 с.

4. В.А. Шаповалов. Солнечный кремний // ВАНT. Серия «Вакуум, чистье материаль, сверхпроводники». 2014, №1(89), с. 53-59.

5. В.Е. Семененко, И.В. Нистеренко. Выращивание и микроструктура AsGa // International scientific conference "Physical and technical problems and their solutions”. 2019, Харков: ХНУ, с. 41-42.

6. A.E. Bolotnikov. Properties of Schottky-type contacts in high-resistance $\mathrm{Cd} \mathrm{Zn} \mathrm{Te} \mathrm{detectors} \mathrm{//} \mathrm{Nucl.}$ Instr. and Math. A. 2009, v. 444, p. 395-407.

7. Н.А. Булычев, М.А. Казарян. Наноразмерные оксиды металлов // Краткие сообщения по физике. М.: ФИАН, 2014, №9, с. 33-37.

8. В.Е. Семененко, А.И. Овчаренко. Международная научно-техническая конференция «Физикотехнические проблемы энергетики и пути их решения 2014»: Тезисы докладов. Харьков: ХНУ им. В.Н. Каразина, 2014, с. 28.

9. S.M. Liang. Materials of Solar battery // J. Phys. Equil and Diff. 2014, N 35(1), p. 35-48.

10. Н.А. Азаренков, В.Е. Семененко, В.А. Позняков. Высокотемпературные естественные микрокомпозиты // Металлофизика новейших технологий. 2011, т. 33, №12, с. 379-391.

11. А.В. Гусев. Выращивание стабильных изотопов кремния // Полупроводниковые материальл. 2008, №2, c. 88-101.

12. Е.В. Пашкова // Наносистемы, наноматериаль, нанотехнологии. 2013, т. 1, №1, с. 601-610.

13. Х. Меррер. Диффузия в твердых телах / Пер. с англ. Долгопрудный: «Интеллект», 2011, с. 535.

14. Н.А. Азаренков, А.С. Посухов, В.Е. Семененко, Н.Г. Стервоедов. Механизмы и фенологическая модель процессов ускорения диффузии // Системи управління навігащіï та зв'язку. 2014, в. 2/16, с. 38-44.

15. V.E. Semenenko, M.M. Pylypenko, V.A. Posnyakov. Dislocation structure of natural microcompasite 
materials // PAST. Series "Vacuum, Pure Materials, Superconductors”. 2009, N 6(64), p. 227-233.

16. A.M. Kosevich. The crystal lattice: Phonons, Solution, Dislocation, Superlattices. Willey-Vergand, Weinheim, 2009, p. 241-248.

17. A. Khan, M. Yamaguchi, J.C. Bourgoin, K. Ando, J. Takamoto. Recombination enhanced defect reaction in $1 \mathrm{MeV}$ electron irradiated p-GaInP // J. Appl. Phys. 2001, v. 89(8), p. 4263-4268.
18. B. Goldstein. Diffusion in compound semiconductors // Bull. Amerk. Phus. Sol. Stade. 2017, Ser. 5, N 1, p. 145-146.

19. O. Zgalaf-Lozynskyy. Nanostructured composite materials // Selicate Industry. 2014, v. 69, N 7-9, p. 147149.

Статья поступила в редакциию 30.10.2019 2.

\title{
ЭВОЛЮЦИЯ ДИСЛОКАЦИОННОЙ СТРУКТУРЫ В ПРОЦЕССЕ ВЫРАЩИВАНИЯ МОНОКРИСТАЛЛОВ КРЕМНИЯ $\boldsymbol{n}$ - И $\boldsymbol{p}$-ТИПОВ
}

\section{Н.А. Азаренков, В.Е. Семененко, Н.Г. Стервоедов}

Рассмотрена кинетика формирования совершенных монокристаллов кремния $n$ - и $p$-типов. Установлена особенность образования точечных и линейных дефектов в процессе контролируемого фазового превращения жидкость-твердое тело. Определено влияние пересыщения вакансиями направления преимущественного роста и концентрации примесей на процесс образования и удаления краевых и винтовых дислокаций. Выяснена роль линейных дефектов на рассеяние и рекомбинацию подвижных носителей тока. Обсуждаются возможности повышения стабильности работы, КПД кремниевых полупроводниковых приборов.

\section{ЕВОЛЮЦІЯ ДИСЛОКАЦІЙНОЇ СТРУКТУРИ В ПРОЦЕСІ ВИРОЩУВАННЯ МОНОКРИСТАЛІВ КРЕМНІЮ $n$ - ТА $p$-ТИПІВ}

\author{
М.О. Азарєнков, В.С. Семененко, М.Г. Стєрвоєдов
}

Розглянута кінетика формування досконалих монокристалів кремнію $n$ - та $p$-типів. Встановлена особливість утворення точкових і лінійних дефектів у процесі контрольованого фазового перетворення рідина-тверде тіло. Визначено вплив пересичення вакансіями напрямку переважного зростання i концентрації домішок на процес утворення і видалення крайових і гвинтових дислокацій. З'ясовано роль лінійних дефектів на розсіяння і рекомбінацію рухомих носіїв струму. Обговорюються можливості підвищення стабільності роботи, ККД кремнієвих напівпровідникових приладів. 